\title{
The Biotransformation and Biodecolorization of Methylene Blue by Xenobiotic Bacterium Ralstonia pickettii
}

\author{
Adi Setyo Purnomo*, Asranudin, Didik Prasetyoko, and Yulinar Dwi Nur Azizah \\ Department of Chemistry, Faculty of Science and Data Analytics, Institut Teknologi Sepuluh Nopember (ITS), \\ Kampus ITS Sukolilo, Surabaya 60111, Indonesia
}

\section{${ }^{*}$ Corresponding author:}

email:adi_setyo@chem.its.ac.id

Received: May 10, 2021

Accepted: August 26, 2021

DOI: $10.22146 /$ ijc. 65806

\begin{abstract}
The biotransformation and biodecolorization of methylene blue (MB) dye using the bacterium Ralstonia pickettii was investigated. This experiment was conducted in a nutrient broth (NB) medium after adding $M B$ at $100 \mathrm{mg} \mathrm{L}^{-1}$ concentration. Approximately $98.11 \%$ of $M B$ was decolorized after $18 \mathrm{~h}$ of incubation. In addition, the metabolic products detected by LC-TOF/MS were Azure A ( $A A)$, thionine, leuco-MB, and glucose- $M B$, which indicated the $M B$ degradation through a reductase that attacked the heterocyclic central chromophore group present in the structure. Moreover, azure A and thionine fragments resulted from the $\mathrm{N}$-demethylase enzyme that attacked the auxochrome group. Thus, this research was assumed to be the first scientific report suggesting the potential to use R. pickettii in the biodecolorization and biotransformation of dye waste, particularly $M B$.
\end{abstract}

Keywords: decolorization; biotransformation; xenobiotic bacteria; Ralstonia pickettii; methylene blue

\section{INTRODUCTION}

Water pollution has become a major problem that can negatively impact humans and the environment [1]. Synthetic dyes are typical water pollutants widely used in the cosmetic, pharmaceuticals, textile, printing, and food industries [2]. In addition, approximately 280,000 tons of dye wastes are discharged into the environment, especially water bodies, without any treatment [3-4]. These direct exposures negatively affect the ecosystem following the interference with sunlight penetration, lowered dissolved oxygen concentration, and disrupted photosynthetic processes for some aquatic organisms [5]. Moreover, other hazardous effects are observed with biomagnification, carcinogenicity, and mutagenicity towards the environment and human health [6-7]. Methylene blue (MB) is one of the dyes used in leather, cotton, cosmetic, plastic, and silk industries [8], especially in the coloring process, where only $5 \%$ is absorbed, while $95 \%$ is released as waste to the aquatic environment [9]. The disposal of the MB directly contaminates humans and causes diseases, including diarrhea, eye damage, vomiting, gastric disorders, methemoglobinemia, headaches, and dizziness, especially in pregnant women and babies [1011]. Furthermore, the death of some aquatic organisms around the disposal area has also been reported [12-13]. This high contamination incidence indicates the need to manage waste before discharge to minimize the negative impacts properly.

Moreover, microbiological treatment approaches using bacteria or fungi are less costly and more effective in handling color substance waste than physical, chemical, photocatalytic, and electrochemical methods [10]. The biodecolorization or biodegradation of dyes ensues through the reductive and oxidative activities produced by various extracellular enzymes, observed at the chromophore and auxochrome sites of the molecules [11]. Specifically, decolorization is initiated by reducing $\mathrm{MB}$ at the molecular level with NADPH-dependent dehydrogenase quinone into a form of leuco-MB [14-15]. The attacks on chromophore groups instigate the opening of aromatic rings within the heterocyclic center, which first produces intermediate compounds estimated to cleave the structures further [16]. Meanwhile, other degradation mechanisms include oxidative 
demethylation by demethylase enzymes, comprising aminopyrine $\mathrm{N}$-demethylase, assumed to interact with the auxochrome group to produce fragmented metabolic products of azure $B(A B)$, azure A (AA), azure C (AC), and thionine [17]. The microbiological approach towards degradation requires various processes influenced by numerous factors, including the reaction substrate type and the wealth of microbial genetic strains [13]. Therefore, different microbes act through various mechanisms produce diverse results after waste treatment [18]. However, some species demonstrate the degradation ability, including Daedalea dickinsii [16], Bacillus subtilis strain MTCC 441 [19], Ralstonia eutropha [20], Alcaligenes species [5], Alcaligenes faecalis [21], Aspergillus niger LAG [22], and Rhodococcus strain UCC 0003 [23]. These microbes potentially remove more than $85 \% \mathrm{MB}$ and are confirmed to affect degradation cases with other xenobiotic wastes.

Ralstonia pickettii is a xenobiotic bacterial with the capacity to biodegrade some organic pollutants. This phenomenon is confirmed by numerous reports obtained with various related wastes, resulting from the metabolic complexity alongside the encoding genes for biodegradation enzymes [24]. Furthermore, the toluene3-monooxygenase, phenol/cresol hydroxylase [25], and meta-cleavage pathway enzymes are secreted to convert catechol and methyl catechol tricarboxylic acid cycle intermediates [26]. These intrinsic constituents promotes the ability to decompose a variety of wastes, including DDT [18], crude oil [27], phenol [28], chlorobenzene [29], toluene and meta-cresol [30], BTEX (benzene, ethylbenzene, toluene, xylenes) [31] and 2,4,6trichlorophenol [30]. The application of $R$. pickettii as a bioremediation agent was more advantageous than other bacteria because of the non-detection as a phytopathogen or pathogen of animals. In addition, reports have shown significant resilience in low-nutrient environments [30], and it is also considered a good choice for the biodecolorization and biodegradation of $\mathrm{MB}$ as well as for broader purposes such as degradation of xenobiotic pollutants (toluene and trichloroethylene) [30], crude oil [27] and pesticide [32]. Therefore, the biotransformation and biodecolorization of $\mathrm{MB}$ dye using the bacterium $R$. pickettii were investigated in this study.

\section{- EXPERIMENTAL SECTION}

\section{Materials}

The bacterium $R$. pickettii NBRC 102503 (NITE Biological Resources Center, Chiba, Japan) was collected from the Microbial Chemistry laboratory. This specimen was maintained as a culture on nutrient agar (NA; Merck, Darmstadt, Germany), while methanol (Merck, 99\%), MB (Merck, C.I. 52015), and D-glucose (Merck-Germany) were purchased from Sumber Ilmiah Persada (SAP, Indonesia).

\section{Procedure}

\section{Biodecolorization of methylene blue by R. pickettii}

A single $R$. pickettii culture was used to biodecolorize $\mathrm{MB}$, which involved inoculating $10 \%$ preincubated bacteria into an Erlenmeyer flask containing $50 \mathrm{~mL}$ nutrient broth and then incubation at $30{ }^{\circ} \mathrm{C}$ for $30 \mathrm{~h}$ [33]. Non-inoculated flasks were prepared as controls. Subsequently, the MB was added to attain a final concentration of $100 \mathrm{mg} \mathrm{L}^{-1}$ before the cultures were placed in a shaker incubator (VELP scientifica) for $18 \mathrm{~h}$ at $30^{\circ} \mathrm{C}$ with a shaking speed of $120 \mathrm{rpm}$. The entire process was monitored for $0,3,6,9,12,15$, and $18 \mathrm{~h}$, with biomass separation, was performed at each time frame to obtain the supernatants, using $2000 \mathrm{G}$ centrifugation for $10 \mathrm{~min}$ [16]. Furthermore, absorbance measurements were carried out with a UV-VIS spectrophotometer at a $400-800 \mathrm{~nm}$ wavelength. In addition, the control group contained a $100 \mathrm{mg} \mathrm{L}^{-1}$ concentration mixture of $\mathrm{NB}$ and $\mathrm{MB}$, while the percentage of sample decolorized was evaluated using the following Eq. (1).

$\%$ Decolorization $=\frac{\mathrm{Ao}-\mathrm{At}}{\mathrm{Ao}} \times 100 \%$

whereas Ao was the absorbance of the control solution while At was the absorbance of the treated sample.

\section{Analysis of metabolic products}

The metabolic products were analyzed by evaluating the filtrates through LC-TOF/MS (AB SCIEX). TM RSLC Acclaim 120 C18 column was also used with a $2.1 \times 100 \mathrm{~mm}$ dimension and set to $33^{\circ} \mathrm{C}$ temperature 
[16]. In addition, ionizing electrospray (ESI) served as a source of ionization within a mass range of 50-500, where the sample elution flow rate was determined and graded

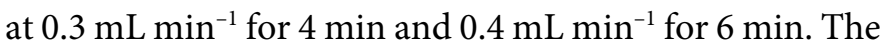
methanol:water mixture $(99: 1 \mathrm{v} / \mathrm{v})$ served as the mobile phase within the first $3 \mathrm{~min}$ and followed by $61: 39 \mathrm{v} / \mathrm{v}$ on the remaining $7 \mathrm{~min}$.

\section{- RESULTS AND DISCUSSION}

\section{Biodecolorization Study}

This study expresses the $R$. pickettii ability to degrade $M B$ in a NB medium. In addition, each culture was inoculated with $1 \mathrm{~mL}$ of pre-incubated bacterium ( $1 \mathrm{~mL}$ bacterium was equivalent to $1.44 \times 10^{13} \mathrm{CFU}$ ), and incubated at $30{ }^{\circ} \mathrm{C}$ for $18 \mathrm{~h}$, with a biodecolorization monitor time of $0,3,6,9,12,15$, and 18. Fig. 1 showed the absorbance profile versus wavelength in which $670 \mathrm{~nm}$ was determined to be the optimum wavelength. The absorbance pattern profiles at $\mathrm{H} 0$ to $\mathrm{H} 9$ showed a small decrease in intensity, although there was a significant difference with the absorbance control MB. These conditions indicated the inability $R$. pickettii during incubation time at $0-9 \mathrm{~h}$ to show structural degradation activities or transformation performance. However, H12H18 (incubation 12 and $18 \mathrm{~h}$, respectively) demonstrated a significant change in the absorbance pattern. In addition, $R$. pickettii was capable of thoroughly countering the MB at H18. The elevated cell biomass also contributes to further dye adsorption and reduced absorbance [16].

The optimum decolorization of $\mathrm{MB}\left(100 \mathrm{mg} \mathrm{L}^{-1}\right)$ by R. pickettii was observed at $18 \mathrm{~h}$ (up to $98.11 \%$ ). This process ensued from the inception of incubation, where $23.33 \%$ was reported. In addition, the t-test indicated significant differences in decolorization between 0 to $12 \mathrm{~h}$, which was stationary from 12 to $18 \mathrm{~h}$ (Table 1 ). Thus, the effects of $R$. pickettii were related to the extracellular enzyme content during the incubation period [23]. Moreover, every microorganism demonstrates varying decolorization strength, possibly attributed to the discrepancies in microbe strains or species, incubation time, dye concentration, and other performance-related supporting factors [21,34].

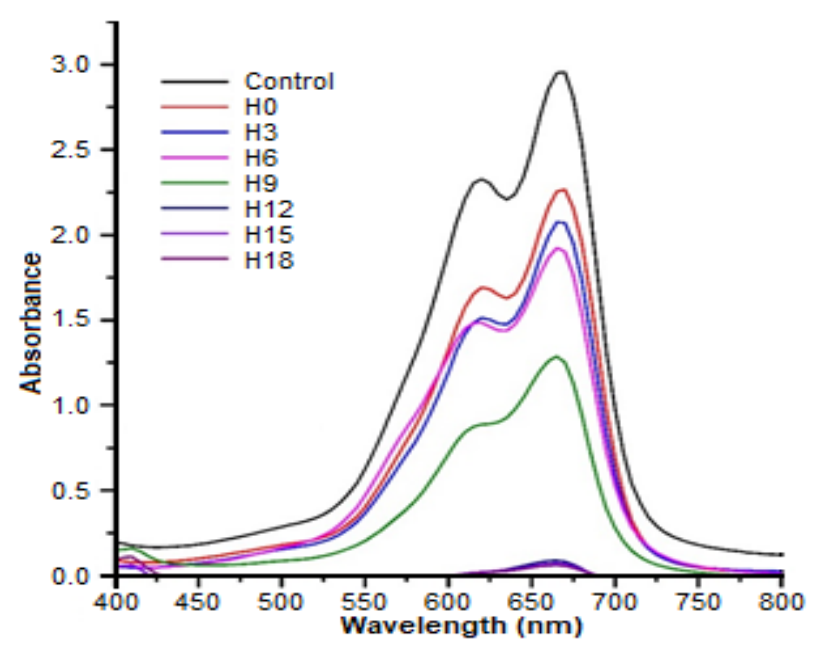

Fig 1. Methylene blue (MB) decolorization absorbance profiles of $R$. pickettii. Data are means $(\mathrm{n}=3)$, where $\mathrm{H} 0$ $=0 \mathrm{~h}, \mathrm{H} 3=3 \mathrm{~h}, \mathrm{H} 18=18 \mathrm{~h}$ incubation

Table 1. Biodecolorization of $\mathrm{MB}$ by $R$. pickettii in nutrient broth during 18-day incubation period

\begin{tabular}{lll}
\hline Incubation time $(\mathrm{h})$ & Absorbance & \% Decolorization \\
\hline Control & $2.95 \pm 0.01$ & - \\
0 & $2.27 \pm 0.07^{\mathrm{a}}$ & $23.33 \pm 0.68^{\mathrm{a}}$ \\
3 & $2.07 \pm 0.11^{\mathrm{b}}$ & $29.94 \pm 0.42^{\mathrm{b}}$ \\
6 & $1.90 \pm 0.02^{\mathrm{c}}$ & $35.64 \pm 0.22^{\mathrm{c}}$ \\
9 & $1.25 \pm 0.21^{\mathrm{d}}$ & $57.71 \pm 0.27^{\mathrm{d}}$ \\
12 & $0.08 \pm 0.04^{\mathrm{e}}$ & $97.21 \pm 0.43^{\mathrm{e}}$ \\
15 & $0.07 \pm 0.02^{\mathrm{e}}$ & $97.70 \pm 0.01^{\mathrm{e}}$ \\
18 & $0.06 \pm 0.03^{\mathrm{e}}$ & $98.11 \pm 0.22^{\mathrm{e}}$ \\
\hline
\end{tabular}

The decolorizing ability of $R$. pickettii was seamless in contrast with other bacteria species, although some bacteria showed satisfactory results, such as Alcaligenes species, with maximum decolorization of $88.06 \%$ (100 $\left.\mathrm{mg} \mathrm{L}^{-1}, 40 \mathrm{~d}\right)$ [5]; Camamonas aquatica at $67 \%\left(50 \mathrm{mg} \mathrm{L}^{-1}\right.$, $96 \mathrm{~h}$ ) [35]; B. subtilis strain MTCC 441 at $91.68 \%$ (20 mg $\mathrm{L}^{-1}, 6 \mathrm{~h}$ ) [19]; Bacillus thuringiensis 016 with $95 \%$ (25 mg $\mathrm{L}^{-1}, 2$ h) [36]; and Bacillus sp. strain MZS10 at $93.55 \%$ $\left(0.04 \mathrm{~g} \mathrm{~L}^{-1}, 14 \mathrm{~h}\right)$ [14]; as well as Bacillus licheniformis strain IFO 12200, Bacillus circulans strain IFO 13626, and Bacillus pomilus strain IFO 12092, with a maximum of $97.5 \% ; 88.0 \%$; $65.0 \%$, respectively $\left(1.1 \times 10^{-5} \mathrm{~mol} \mathrm{~L}^{-1}\right.$, $24 \mathrm{~h}$ ) [37]. In addition, some fungi also confer these effects on $\mathrm{MB}$, although longer incubation is time required. These fungi were Phanerochaete chrysosporium, with maximum decolorization of $84.8 \%$ 
(0.4 $\left.\mathrm{g} \mathrm{L}^{-1}, 22 \mathrm{~d}\right)$ [36]; D. dickinsii at 54\% (50 $\left.\mathrm{mg} \mathrm{L}^{-1}, 14 \mathrm{~d}\right)$ [16], while Phaseolus coccineus, Coriolus versicolor, Fomes fomentarius, Trametes suaveolens, and Stereum ostrea decolorized approximately $40 \%\left(100 \mathrm{mg} \mathrm{L}^{-1}, 20 \mathrm{~d}\right)$ [38].

The early interaction with $\mathrm{MB}$ ensues on the cell wall surface, which is achieved through adsorption and ionic interactions between the negative charge of the carboxylate $(-\mathrm{COOH})$ or hydroxyl $(-\mathrm{OH})$ group and the positive $\mathrm{MB}$ charge [19]. The reactions possibly occur via the reduction of $\mathrm{MB}$ to leuco-MB. In addition, extracellular enzymes, including NADH/NADPH-dependent reductase, are widely reported to be responsible for the procedure, as shown in Fig. 2, where colorless Leuco-MB was generated [39]. This reaction also requires oxidative dehydrogenation to yield products characterized by the potential to produce hydrogen peroxide with functionalities through other media or to be decomposed into $\mathrm{O}_{2}$ and $\mathrm{H}_{2} \mathrm{O}$ molecules [40]. This reaction demonstrates redox properties with $\mathrm{MB}$, hence the tendency to use staining and cell density detection. In addition, color loss indicates a substantial cell population implicated in surface adsorption and reduction of MB [41].

The dye decolorization process ensued through a different mechanism for various microorganisms[23,32], where the carbon and nitrogen sources influence the cell's ability to act effectively [14]. The procedure possibly occurs through enzyme and non-enzyme (Fenton) mechanisms, and the latter is adopted with brown-rot fungi [16,42-43]. In addition, some other enzyme groups exploited for dye decolorization include azoreductase [44], lignin peroxidases [38], laccase [45], manganese peroxidase [17], peroxidase and polyphenol oxidase [39], and microperoxidase-11 [46]. The MB in this current investigation was exposed to biotransformation and biodegradation. In addition, the resulting metabolic products were generated through reduction and demethylation reactions on the structure. These mechanisms ensure the support provided by the extracellular enzymatic activities of $R$. pickettii in a liquid NB medium [38].

\section{Identification of Metabolic Products}

The MB metabolic products generated after biodegradation treatment with $R$. pickettii were identified using LC-TOF/MS, as shown in Fig. 3. Furthermore, the LC-TOF/MS chromatogram demonstrates 4 metabolic product peaks, where one with a retention time of $5.57 \mathrm{~min}$ indicated $\mathrm{MB}$ molecule at $\mathrm{m} / \mathrm{z}=284[14,16]$. Remarkably, the intensity was lower than the control, further confirming the sample transformation within the incubation period, following the incidence of extracellular metabolic products activities. Fig. 3 showed the 4 peaks, characterized by retention times of 2.67, 5.01, 6.49, and $7.79 \mathrm{~min}$, with each possessing an $\mathrm{m} / \mathrm{z}$ value of 256 (azure A) [14,17], 224 (thionine) [47], 285 (leuco-MB) [15], and 447 (glucose-MB) [14], respectively.

The yields from each microorganism comprised different fragments of compounds, which applied bacteria or fungi outputs [5,16]. In addition, photocatalytic decomposition processes yield a variety of smaller and large molecular fragments [47]. The mechanisms mostly adopted currently involve the working principle of microbes, photocatalytic, and a combination of both mechanisms. Fig. 3 showed the LCTOF/MS chromatogram and further demonstrated $R$. pickettii transforming $\mathrm{MB}$ into some metabolic products, including azure $\mathrm{A}$, thionine, Leuco-MB, and Glu-MB. Moreover, certain bacteria or fungi were identified to yield similar output, although some of them were also different. The Alcaligenes species yielded 4amino-1-benzylpiperidinium dichloride $\left(\mathrm{C}_{12} \mathrm{H}_{18} \mathrm{ClN}_{2}\right)$ and

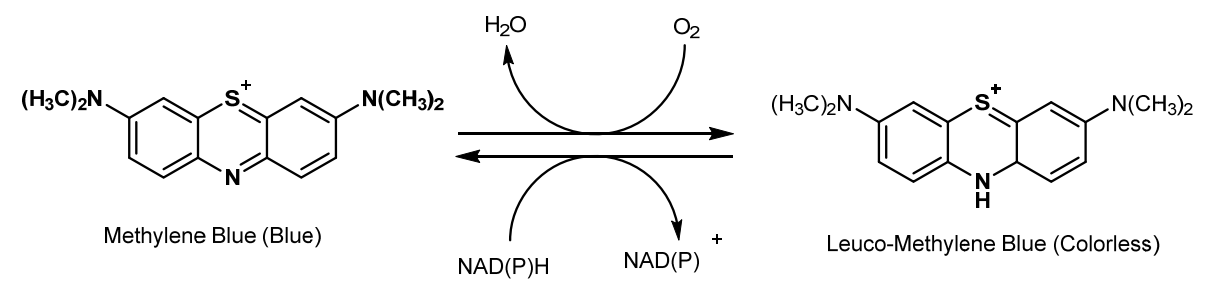

Fig 2. Redox cycling of Methylene blue (MB) 


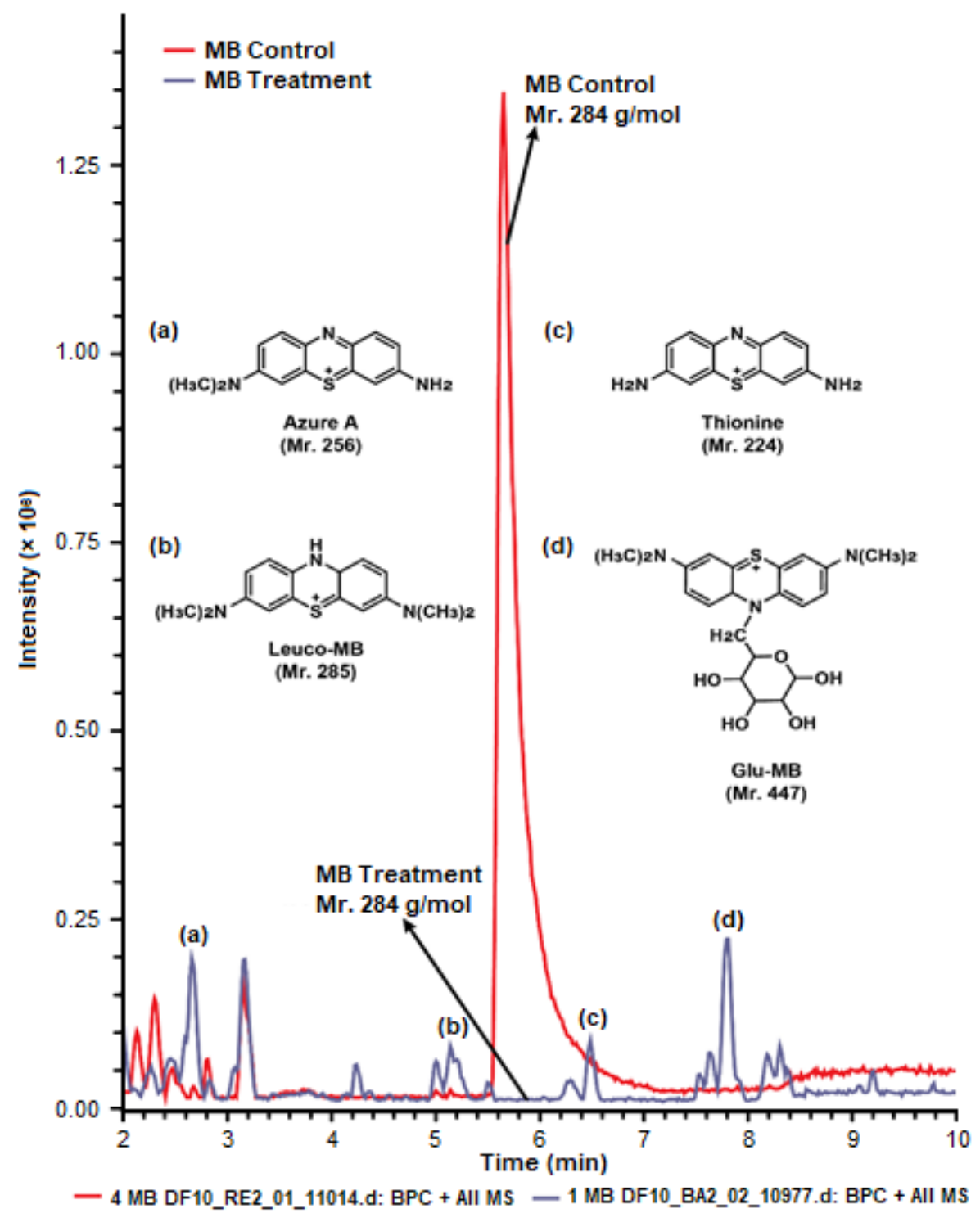

Fig 3. LC-MS chromatogram profile of MB transformation by $R$. pickettii

4,4'-diaminodiphenyl sulfide $\left(\mathrm{C}_{12} \mathrm{H}_{12} \mathrm{~N}_{2} \mathrm{~S}\right)$ [5], while azure B $\quad(\mathrm{m} / \mathrm{z}=270) ; 3,7-$ bis (dimethylamino)-4aHphenothiazin-5-one $(\mathrm{m} / \mathrm{z}=300)$, and 4 -(dimethylamino)2-[m-(dimethylamino) phenyl sulfinyl] benzenamine were observed with $D$. dickinsii $(\mathrm{m} / \mathrm{z}=303)$ [16]. Fig. 4 showed the summary for the proposed $\mathrm{MB}$ transformation pathway using 3 microbes.

The molecular fragments identified as products after treatment with photocatalytic and natural oxidizing agents were more diverse, despite the similarity between some metabolic products of bacteria or fungi, including azure $\mathrm{A}$, azure $\mathrm{B}$, and thionine [47]. The $\mathrm{MB}$ degradation process using natural $\mathrm{MnOx}$ yielded 7 metabolic products, comprising azure $B(\mathrm{~m} / \mathrm{z}=270)$, azure $A(\mathrm{~m} / \mathrm{z}$ = 256), 2-methyl-2,3,4,5-tetrahydro-1,4-thiazin-1-ium $(\mathrm{m} / \mathrm{z}=115), 7$-amino-2,3-dimethylbenzo[b][1,4]thiazin1-ium $(\mathrm{m} / \mathrm{z}=186)$, benzene-1,4-diamine $(\mathrm{m} / \mathrm{z}=105)$, benzo[b][1,4]thiazin-1-ium $(\mathrm{m} / \mathrm{z}=156)$, and aniline $(\mathrm{m} / \mathrm{z}=98.5)$ [17]. Meanwhile, photocatalysis with materials from sugarcane bagasse cellulose (SBC)- $\mathrm{TiO}_{2}$ generated fragments of $\mathrm{C}_{16} \mathrm{H}_{21} \mathrm{~N}_{3} \mathrm{SO}, \mathrm{C}_{16} \mathrm{H}_{19} \mathrm{~N}_{3} \mathrm{~S}$ (azure B), $\mathrm{C}_{8} \mathrm{H}_{12} \mathrm{~N}_{2} \mathrm{SO}_{3}, \mathrm{C}_{6} \mathrm{H}_{7} \mathrm{NO}$, and $\mathrm{C}_{6} \mathrm{H}_{7} \mathrm{~N}$ [11]. The use of $\mathrm{ZnO}: \mathrm{Eu}$ nanoparticles under the sun rays produced a similar outcome as observed with $R$. picketii, while leuco-MB and azure B were identified with $D$. dickinsii [48]. In addition, the microbes and material sources 
considerably influenced the variations between specific metabolic products produced. The degradation mechanisms adopted by each bacteria or fungi are associated with the intrinsic enzyme complexity enzymes $[4,16,33]$, while photocatalysis is influenced by the energy source and the material composition [47].

The microbial approach is entirely controlled by extracellular enzyme activities [49]. Furthermore, the effects on synthetic dyes are generally achieved through varied mechanisms to attain a structural transformation. These bacteria and fungi secrete extracellular enzymes after induction in the media. Moreover, R. pickettii was presumed to affect modifications to $\mathrm{MB}$ by involving the reductase enzymes, including quinone dehydrogenase (QD) dependent NADPH and demethylase. Mainly, QD is an enzyme involved in xenobiotic metabolism processes and confers protection from quinone free radical derivatives [50]. The reductase enzyme, including azo reductase, influences azo dye degradation, with a specific effect on the bond $-\mathrm{N}=\mathrm{N}-$ [39]. These enzymatic involvements are based on the metabolic products identified in the LC-MS analysis (see Fig. 3).

\section{Proposed Methylene Blue (MB) Transformation Pathway}

The identification for metabolic produced during MB degradation, using LC-TOP/MS, and determined based on the approximate pathway after transformation by $R$. pickettii showed in Fig. 4. The proposed procedure recognized the essential roles played by $\mathrm{QD}$ in the decolorization process by the hydrogenation of $\mathrm{MB}$ to form colorless Leuco-MB. The proposed procedure recognized the essential roles played by $\mathrm{QD}$ in the decolorization process by the hydrogenation of $\mathrm{MB}$ to form colorless Leuco-MB. This output is more stable, resulting from the Glucose-MB molecules formed by dehydration between the hydroxyl group $(-\mathrm{OH})$ from glucose and the -NH present in MB [14]. Furthermore, QD was produced and identified in some bacteria, including the Bacillus sp. strain MZS10 and Bacillus sp. strain LD003, following the degradation of dye azure B [50].

The biodecolorization process is generally attributed to enzymatic oxidation or reduction activities. These are some of the various extracellular types involved: $\mathrm{H}_{2} \mathrm{O}_{2}$

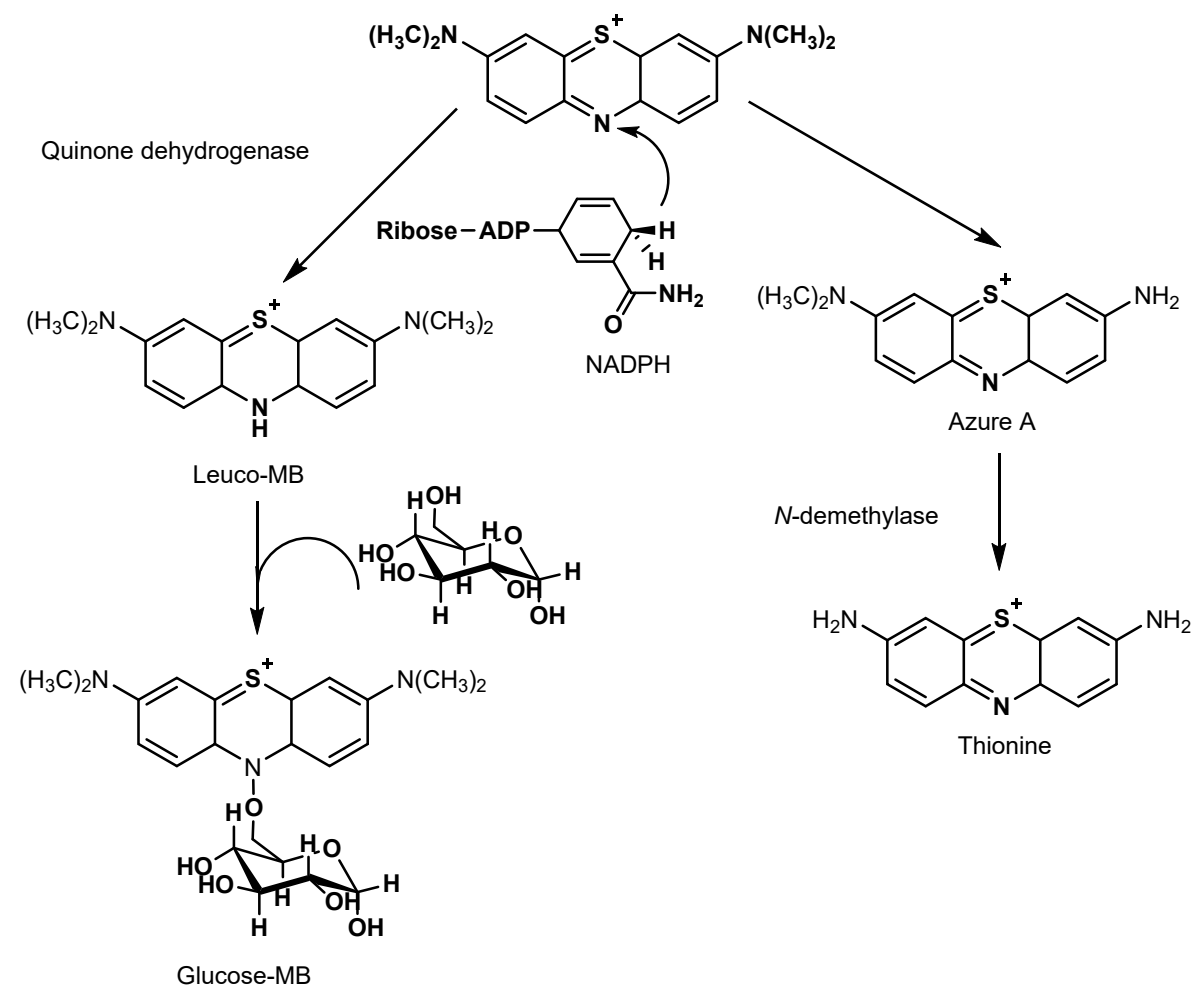

Fig 4. Proposed methylene blue (MB) transformation pathway by $R$. pickettii 
independent oxidase, laccase, and azoreductase to degrade the reactive yellow of $84 \mathrm{~A}$ by Exiguobacterium sp. $\mathrm{RD} 3$ [51]. Also, Pseudomonas aeruginosa $\mathrm{BCH}$ is known to secrete tyrosinase, NADH-DCIP reductase, veratryl alcohol oxidase, and laccase are implicated in amaranth azo dye decomposition [52].

Fig. 4 showed oxidative demethylation of $M B$ as another mechanism exploited to form azure A (AA) and thionine molecules. Particularly, demethylation commonly facilitates the conversion into azure $B(A B)$, azure $A(A A)$ or sym-dimethylthionine, Azure $\mathrm{C}(\mathrm{AC})$, and thionine [50]. Fig. 5 showed the degradation in potato dextrose broth (PDB), using $D$. dickinsii to produce azure $\mathrm{B}$ molecules. Conversely, oxidation with sulfur and reduction at the $\mathrm{C}=\mathrm{N}$ bond instigated the production of 3,7bis(dimethylamino)-4aH-phenothiazine-5-one and 4(dimethylamino)-2-[ $m$-(dimethylamino)-phenylsulfinyl] benzenamine [16]. Furthermore, the MB degradation process involving Alcaligenes generated a derivative with smaller BM. This effect was attributed to enzymes secreted to perform total demethylation and $\mathrm{C}=\mathrm{N}$ bond reduction resulting in the 4,4-diaminodiphenyl sulfide fragment [5]. In addition, other metabolic products emanated from demethylation, deamination, and oxidation procedures, with characteristic fragments of 4-amino-1-benzylpiperidinium dichloride [5]. The Lignin peroxidase (LiP) and horseradish peroxidase (HRP) from $P$. chrysosporium instigated the demethylation of $\mathrm{MB}$ and azure B. Based on HPLC analysis, the HRP produced more derivatives $(\mathrm{AB}, \mathrm{AA}$, $\mathrm{AC})$ than the LiP, while individual activity depended on $\mathrm{H}_{2} \mathrm{O}_{2}$ concentration [53].

Moreover, there are limited detailed reports on demethylation reaction mechanisms involving microbes, as most were based only on the modification approach towards the groups present on the metabolic product. Therefore, the biodegradation of dyes with $R$. pickettii has not been substantially evaluated, and the predominant enzymes involved are not currently identified. Today, the enzymes identified in R. pickettii involved in the degradation of xenobiotic pollutants are oxygenase groups such as catechol-1,2-dioxygenase and hydroxyquinol-1,2-dioxygenase [24,30].

Furthermore, there have been extensive studies on demethylation, including the oxidative aminopyrine approach, involving various enzyme types, e.g., microsomal cytochrome P-450, HRP, metmyoglobin, and protohemin [54]. The catalytic demethylation on dye

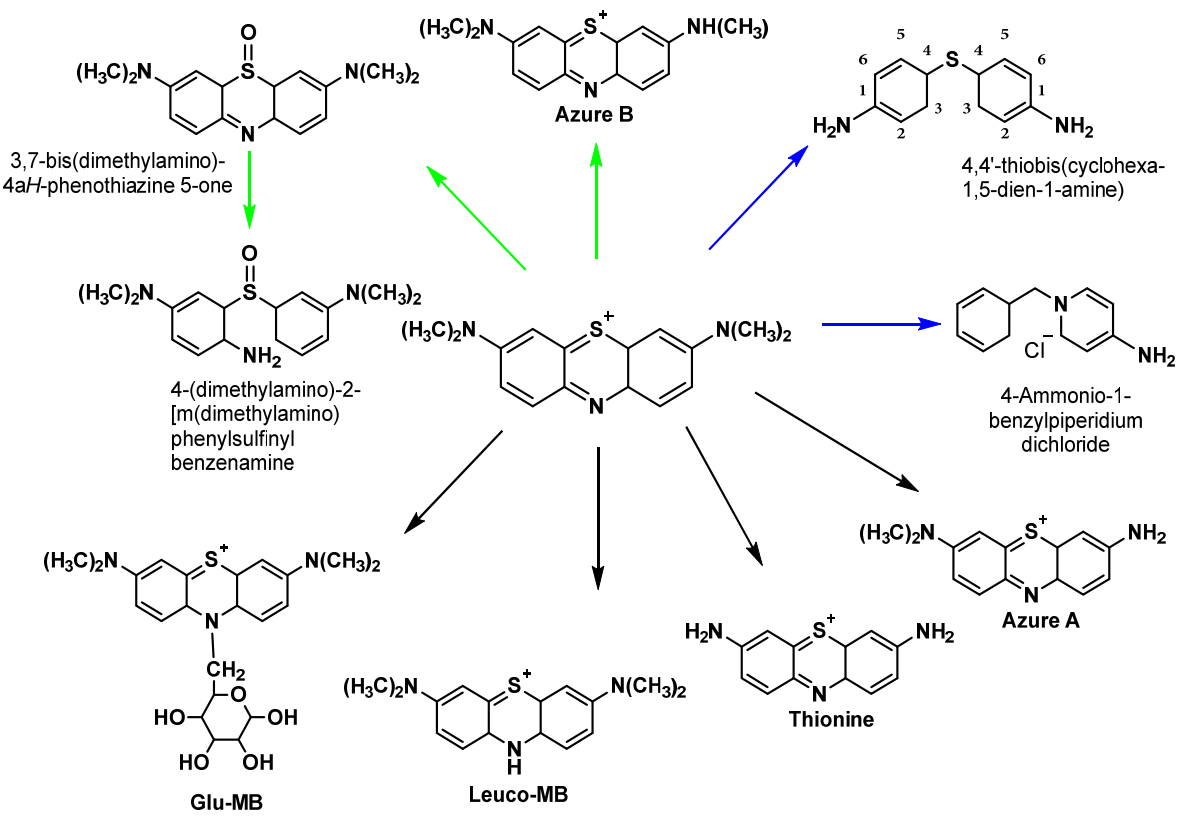

Fig 5. Summary of the proposed methylene blue (MB) transformation pathway by R. pickettii (black line; this study), Alcaligenes (blue line) [21], D. dickinsii (green line) [16] 
structure was reported to have occurred during biodegradation through a similar mechanism, although with aminopyrine $\mathrm{N}$-demethylase (AND). This pathway was confirmed during the bio-decomposition of Direct Blue- 6 by Pseudomonas desmolyticum strain NCIM 2112 [55] and methyl red by Brevibacillus laterosporus strain MTCC 2298.

In addition, several enzyme types were also involved in the structural biotransformation of methyl red, including lignin peroxidase, laccase, NADH-DCIP reductase, and malachite green reductase [10]. The AND catalytic activity was also detected after the decolorization of Red BLI by Pseudomonas sp. SUK1 [56]. Moreover, the demethylation mechanisms exhibited with some dyes involve the activity of various enzymes, encompassing laccase at Brown 3REL [57], lignin peroxidation to convert $\mathrm{N}, \mathrm{N}, \mathrm{N}^{\prime}, \mathrm{N}^{\prime}, \mathrm{N}^{\prime \prime}, \mathrm{N}^{\prime \prime}$-hexamethylpararosaniline (crystal violet) into $\mathrm{N}, \mathrm{N}, \mathrm{N}^{\prime}, \mathrm{N}^{\prime}, \mathrm{N}^{\prime \prime}$-penta-, N,N,N',N"tetramethyl pararosaniline, and N,N',N"trimethylpararosaniline [58]. The demethylation at crystal violet ensued in the intermediate compounds Michler's Ketone by Shewanella sp. strain NTOU1 [59].

Furthermore, MB degradation through microbial mechanisms is similar to the photocatalytic method, based on generated metabolic products. The latter showed decomposition or structural transformation by attacks on the chromophores and auxochrome units. Particularly, $R$. pickettii predominantly decomposed the dye at the auxochrome to yield fragments of demethylation, including azure $\mathrm{A}$ and thionine. In addition, similar pathway and metabolic products were reported with $D$. dickinsii [16], and Bacillus sp. strain MZS10 [14]. The decomposition through a group of auxochrome with photocatalytic techniques using P2ABSA-modified $\mathrm{TiO}_{2}$ nanocomposite yielded more organized demethylation products, comprising azure $\mathrm{B}, \mathrm{A}, \mathrm{C}$, and thionine. However, chemical agents, including manganese oxides, also generate compounds between azure $\mathrm{B}$ and $\mathrm{A}$ [17]. The chromophore pathway (a conjugation system of N-S on the core aromatic ring) involving attacks by hydroxyl radical, which instigate the opening of a center aromatic ring, is implicated in the production of intermediate compounds. These include 3-((3-(dimethylamino)-cyclo hexa-2,4-
dien-1-yl)sulfinyl)-N,N'-dimethyl benzene-1,4-diamine $\left(\mathrm{C}_{16} \mathrm{H}_{23} \mathrm{~N}_{3} \mathrm{OS} ; \mathrm{m} / \mathrm{z}=303\right)$ [47]. Meanwhile, compounds related to $\mathrm{C}_{16} \mathrm{H}_{23} \mathrm{~N}_{3} \mathrm{OS}$ were also recognized during biodegradation using $D$. dickinsii and combined with photocatalytic-biodegradation $[11,16]$.

These biological, chemical, photocatalytic approaches and the combination, initiated with the group of chromophores, facilitate cleavage development at the center aromatic ring of $\mathrm{MB}$ and generate monocyclic fragments. Simultaneously, degradation observed on the auxochrome group yields intermediate demethylation products, including azure $\mathrm{B}, \mathrm{A}$, and $\mathrm{C}$, and thionine, before advanced decomposition into simpler compounds. Table 2 shows the summary of $\mathrm{MB}$ metabolic products after degradation through various means. The intermediate compounds generated, including 3-((3-(dimethylamino)cyclohexa-2,4-dien-1yl)sulfinyl)-N,N'-dimethyl benzene-1,4-diamine $\left(\mathrm{C}_{16} \mathrm{H}_{23}\right.$ $\mathrm{N}_{3} \mathrm{OS} ; \mathrm{m} / \mathrm{z}=303$ ) were first identified after the sulfhydryl group $\left(-\mathrm{C}-\mathrm{S}^{+}=\mathrm{C}\right)$ was oxidized. An electron rearrangement process characterizes this into $\mathrm{C}-\mathrm{S}(=\mathrm{O})$ $\mathrm{C}$, which leads to the opening of a center aromatic ring required before the intermediate compounds are formed. The reaction mechanism involves photocatalysis [47-48], Fenton [60], oxidizing agents [17], and microbes [16], instigated by hydroxyl radical attacks.

Furthermore, advanced degradation is experienced after cleavage at the heterocyclic center to yield a variety of simple fragments, including 4-amino-1benzylpiperidinium dichloride $\left(\mathrm{C}_{12} \mathrm{H}_{18} \mathrm{ClN}_{2}, \mathrm{~m} / \mathrm{z}=\right.$ 225.74) and 4,4'-diaminodiphenyl sulfide $\left(\mathrm{C}_{12} \mathrm{H}_{12} \mathrm{~N}_{2} \mathrm{~S}\right.$, $\mathrm{m} / \mathrm{z}=216)$ [5]. The structure auxochrome of $\mathrm{MB}$ are decomposed through oxidative demethylation to produce azure $\mathrm{B}, \mathrm{A}, \mathrm{C}$, and thionine molecules as intermediates. These specimens are estimated to encounter advanced metabolism for subsequent conversion into simpler compounds. The ability for $R$. pickettii to transform MB on a group of chromophores and auxochrome indicates the potency for microbes to prevent dye wastes. In addition, there are numerous records on the capacity to degrade a variety of xenobiotic wastes due to the genetic complexity used to encode various degradation-related enzymes [24,27-28,30,42]. 
Table 2. A comparison of different metabolic products for the treatment of MB

\begin{tabular}{|c|c|c|c|c|c|}
\hline Microbial/Material & & Metabolic products & $\mathrm{m} / \mathrm{z}$ & Analytical method & Ref. \\
\hline \multirow{3}{*}{ D. dickinsii } & 1 & Azure B & 270 & \multirow{3}{*}{ LC-MS } & \multirow{3}{*}[16]{} \\
\hline & 2 & $\begin{array}{l}\text { 3,7-bis(dimethylamino)-4aH-phenothiazin-5-one } \\
\left(\mathrm{C}_{16} \mathrm{H}_{19} \mathrm{~N}_{3} \mathrm{~S}\right)\end{array}$ & 300 & & \\
\hline & 3 & $\begin{array}{l}\text { 4-(dimethylamino }) 2-[m(\text { dimethylamino }) \text { phenylsulfinyl }] \\
\text { benzenamine }\left(\mathrm{C}_{16} \mathrm{H}_{2} 1 \mathrm{~N}_{3} \mathrm{SO}\right)\end{array}$ & 303 & & \\
\hline \multirow{2}{*}{ Alcaligenes } & 1 & 4-amino-1-benzylpiperidinium dichloride $\left(\mathrm{C}_{12} \mathrm{H}_{18} \mathrm{ClN}_{2}\right)$ & 225.74 & \multirow{2}{*}{ GC-MS } & \multirow{2}{*}[5]{} \\
\hline & 2 & 4,4'-diaminodiphenyl sulfide $\left(\mathrm{C}_{12} \mathrm{H}_{12} \mathrm{~N}_{2} \mathrm{~S}\right)$ & 216.3 & & \\
\hline \multirow{2}{*}{ Bacillus sp. MZS10 } & 1 & Azure $\mathrm{B}\left(\mathrm{C}_{15} \mathrm{H}_{16} \mathrm{~N}_{3} \mathrm{~S}\right)$ & 270 & \multirow{2}{*}{ UPLC-MS } & \multirow{2}{*}[14]{} \\
\hline & 2 & Azure A $\left(\mathrm{C}_{14} \mathrm{H}_{14} \mathrm{~N}_{3} \mathrm{~S}\right)$ & 256 & & \\
\hline \multirow{4}{*}{ R. pickettii } & 1 & Azure $\mathrm{A}\left(\mathrm{C}_{14} \mathrm{H}_{14} \mathrm{~N}_{3} \mathrm{~S}\right)$ & 256 & \multirow{4}{*}{ LC-MS } & \multirow{4}{*}{$\begin{array}{l}\text { This } \\
\text { study }\end{array}$} \\
\hline & 2 & Thionine $\left(\mathrm{C}_{12} \mathrm{H}_{10} \mathrm{~N}_{3} \mathrm{~S}\right)$ & 228 & & \\
\hline & 3 & Leuco-MB & 285 & & \\
\hline & 4 & Glucose- $\mathrm{MB}\left(\mathrm{C}_{22} \mathrm{H}_{31} \mathrm{~N}_{3} \mathrm{SO}_{5}\right)$ & 447 & & \\
\hline \multirow{7}{*}{$\mathrm{MnOx}$} & 1 & Azure B & 270.1 & \multirow{7}{*}{ HPLC-MS } & \multirow{7}{*}[17]{} \\
\hline & 2 & Azure A & 256.1 & & \\
\hline & 3 & 7-amino-2,3-dimethylbenzo[b] $[1,4]$ thiazin-1-ium & 191.06 & & \\
\hline & 4 & Benzo[b] $[1,4]$ thiazin-1-ium & 148.02 & & \\
\hline & 5 & 2-methyl-2,3,4,5-tetrahydro-1,4-thiazin-1-ium & 116.05 & & \\
\hline & 6 & Benzene-1,4-diamine & 108.7 & & \\
\hline & 7 & Aniline & 93 & & \\
\hline \multirow{5}{*}{$\begin{array}{l}\text { Photocatalysis- } \\
\text { Biodegradation }\end{array}$} & 1 & $\begin{array}{l}\text { 3-((3-(dimethylamino) cyclohexa-2,4-dien-1-yl) sulfinyl)- } \\
N, N^{\prime} \text {-dimethylbenzene-1,4-diamine }\end{array}$ & 303.30 & \multirow{5}{*}{ HPLC-MS } & \multirow{5}{*}[11]{} \\
\hline & 2 & $\begin{array}{l}\text { 3,7-bis (dimethylamino)-10,10a-dihydro-4aH- } \\
\text { phenothiazine 5-oxide }\end{array}$ & 301.14 & & \\
\hline & 3 & 2-amino-5-(dimethylamino) benzenesulfonic acid & 216.17 & & \\
\hline & 4 & 2-aminophenol & 109.10 & & \\
\hline & 5 & Aniline & 93 & & \\
\hline \multirow{9}{*}{$\begin{array}{l}\text { P2ABSA-modified } \\
\mathrm{TiO}_{2} \\
\text { nanocomposite }\end{array}$} & 1 & Azure B & 270 & \multirow{9}{*}{ UHR-TOF-MS } & \multirow{9}{*}[47]{} \\
\hline & 2 & Azure A & 256 & & \\
\hline & 3 & Azure C & 242 & & \\
\hline & 4 & Thionine & 228 & & \\
\hline & 5 & Phenol & 94 & & \\
\hline & 6 & $\begin{array}{l}\text { 3-((3-(dimethylamino) cyclohexa-2,4-dien-1-yl) sulfinyl)- } \\
N, N^{\prime} \text {-dimethylbenzene-1,4-diamine }\end{array}$ & 303.30 & & \\
\hline & 7 & 2-amino-5-( $N$-methylformamido) benzenesulfonic acid & 230 & & \\
\hline & 8 & $\begin{array}{l}\text { 2-amino-4-hydroxy-5-(methylamino) benzenesulfonic } \\
\text { acid }\end{array}$ & 218 & & \\
\hline & 9 & benzenesulfonic acid & 158 & & \\
\hline
\end{tabular}

\section{- CONCLUSION}

R. pickettii was able to decolorize and degrade the molecular structure of MB. Approximately $98.11 \%$ of MB was decolorized after $18 \mathrm{~h}$ of incubation. Based on the analysis of metabolic products, $R$. pickettii was revealed to have the ability of $\mathrm{MB}$ transformation into Azure A (AA), thionine, leuco-MB, and glucose-MB, which indicated the $\mathrm{MB}$ degradation through a reductase that 
attacks the heterocyclic central chromophore group present in the structure. Moreover, azure A and thionine fragments resulted from the attacks on the auxochrome group by $N$-demethylase enzyme. This research provides evidence for the potential to use $R$. pickettii in the biodecolorization and biotransformation of dye waste, particularly MB.

\section{- REFERENCES}

[1] Tkaczyk, A., Mitrowska, K., and Posyniak, A., 2020. Synthetic organic dyes as contaminants of the aquatic environment and their implications for ecosystems: A review, Sci. Total Environ., 717, 137222.

[2] Bommavaram, K., Bhattacharjee, A., Yadav, D., Andra, N., Pandey, P., and Ibrahim, H., 2020, Tea residue as a bio-sorbent for the treatment of textile industry effluents, Int. J. Environ. Sci. Technol., 17 (7), 3351-3364.

[3] Abu-Talha, M., Goswami, M., Giri, B.S., Sharma, A., Rai, B.N., and Singh, R.S., 2018, Bioremediation of Congo red dye in immobilized batch and continuous packed bed bioreactor by Brevibacillus parabrevis using coconut shell biochar, Bioresour. Technol., 252, 37-43.

[4] Purnomo, A.S., and Mawaddah, M.O., 2020, Biodecolorization of methyl orange by mixed cultures of brown-rot fungus Daedalea dickinsii and bacterium Pseudomonas aeruginosa, Biodiversitas, 21 (5), 2297-2302.

[5] Geed, S.R., Samal, K., and Tagade, A., 2019, Development of adsorption-biodegradation hybrid process for removal of methylene blue from wastewater, J. Environ. Chem. Eng., 7 (6), 103439.

[6] Zhou, Y., Lu, J., Zhou, Y., and Liu, Y., 2019, Recent advances for dyes removal using novel adsorbents: A review, Environ. Pollut., 252, 352-365.

[7] Shah, M.P., 2019, Chapter 6 - Bioremediation of azo dye" in Microbial Wastewater Treatment, Eds. Shah, M.P., and Rodriguez-Couto, S., Elsevier, Netherlands, 103-126.

[8] Zaini, M.A.A., Ngiik, T.C., Kamaruddin, M.J., Mohd. Setapar, S.M., and Che Yunus, M.A., 2014, Zinc chloride-activated waste carbon powder for decolourization of Methylene blue, Jurnal Teknologi, 67 (2), 37-44.

[9] Ehrampoush, M.H., Moussavi, G.R., Ghaneian, M.T., Rahimi, S., and Ahmadian, M., 2011, Removal of methylene blue dye from textile simulated sample using tubular reactor and $\mathrm{TiO}_{2} / \mathrm{UV}-\mathrm{C}$ photocatalytic process, Iran. J. Environ. Health Sci. Eng., 8 (1), 35-40.

[10] Kurade, M.B., Waghmode, T.R., Xiong, J.Q., Govindwar, S.P., and Jeon, B.H., 2019, Decolorization of textile industry effluent using immobilized consortium cells in upflow fixed bed reactor, J. Cleaner Prod., 213, 884-891.

[11] Xiong, J., Guo, S., Zhao, T., Liang, Y., Liang, J., Wang, S., Zhu, H., Zhao, J.R., and Chen, G., 2020, Degradation of methylene blue by intimate coupling photocatalysis and biodegradation with bagasse cellulose composite carrier, Cellulose, 27 (6), 3391-3404.

[12] Boelan, E.G., and Purnomo, A.S., 2018, Abilities of Co-cultures of white-rot fungus Ganoderma lingzhi and bacteria Bacillus subtilis on biodegradation DDT, J. Phys.: Conf. Ser., 1095, 012015.

[13] Sariwati, A., Purnomo, A.S., and Kamei I., 2017, Abilities of co-cultures of brown-rot fungus Fomitopsis pinicola and Bacillus subtilis on biodegradation of DDT, Curr. Microbiol., 74 (9), 1068-1075.

[14] Li, H, Zhang, R, Tang, L., Zhang, J., and Mao, Z., 2014, Evaluation of Bacillus sp. MZS10 for decolorizing Azure B dye and its decolorization mechanism, J. Environ. Sci., 26 (5), 1125-1134.

[15] Schirmer, R.H., Adler, H., Pickhardt, M., and Mandelkow, E., 2011, Lest we forget you methylene blue, Neurobiol. Aging, 32 (12), 2325.e72325.e16.

[16] Rizqi, H.D., and Purnomo, A.S., 2017, The ability of brown-rot fungus Daedalea dickinsii to decolorize and transform methylene blue dye, World J. Microbiol. Biotechnol., 33 (5), 92.

[17] Zhou, S., Du, Z., Li, X., Zhang, Y., He, Y., and Zhang, Y., 2019, Degradation of methylene blue by 
natural manganese oxides: Kinetics and transformation products, R. Soc. Open Sci., 6 (7), 190351.

[18] Purnomo, A.S., Rizqi, H.D., Fatmawati, S., Putro, H.S., and Kamei, I., 2018, Effects of bacterium Ralstonia pickettii addition on DDT biodegradation by Daedalea dickinsii, Res. J. Chem. Environ., 22, 151-156.

[19] Upendar, G., Dutta, S., Bhattacharya, P., and Dutta, A., 2017, Bioremediation of methylene blue dye using Bacillus subtilis MTCC 441, Water Sci. Technol., 75 (7), 1572-1583.

[20] Habibi, A., and Mehrabi, Z., 2017, Aerobic degradation of methylene blue from colored effluents by Ralstonia eutropha, Pollution, 3 (3), 395-406.

[21] Bharti, V., Vikrant, K., Tiwari, H., Sonwani, R.K., Lee, J., Tsang, D.C.W., Kim, K.H., Saeed, M., Kumar, S., Rai, B.N., Giri, B.S., and Singh, R.S., 2019, Biodegradation of methylene blue dye in a batch and continuous mode using biochar as packing media, Environ. Res., 171, 356-364.

[22] Bankole, P.O., Adekunle, A.A., and Govindwar, S.P., 2019, Demethylation and desulfonation of textile industry dye, thiazole yellow $\mathrm{G}$ by Aspergillus niger LAG, Biotechnol. Rep., 23, e00327.

[23] Maniyam, M.N., Hari, M., and Yaacob, N.S., 2020, Enhanced methylene blue decolourization by Rhodococcus strain UCC 0003 grown in banana peel agricultural waste through response surface methodology, Biocatal. Agric. Biotechnol., 23, 101486.

[24] Ryan, M.P., Pembroke, J.T., and Adley, C.C., 2011, Genotypic and phenotypic diversity of Ralstonia pickettii and Ralstonia insidiosa isolates from clinical and environmental sources including high-purity water, diversity in Ralstonia pickettii, BMC Microbiol., 11 (1), 194.

[25] Byrne, A.M., and Olsen, R.H., 1996, Cascade regulation of the toluene-3-monooxygenase operon (tbuA1UBVA2C) of Burkholderia pickettii PKO1: Role of the tbuAl promoter (PtbuAl) in the expression of its cognate activator, TbuT, $J$. Bacteriol., 178 (21), 6327-6337.
[26] Purnomo, A.S., Rizqi, H.D., Harmelia, L., Anggraeni, S.D., Melati, R.E., Damayanti, Z.H., Shafwah, O.M., and Kusuma, F.C., 2019, Biodegradation of crude oil by Ralstonia pickettii under high salinity medium, MJFAS, 15 (3), 377380.

[27] Al-Zuhair, S., and El-Naas, M.H., 2012, Phenol biodegradation by Ralstonia pickettii extracted from petroleum refinery oil sludge, Chem. Eng. Commun., 199 (9), 1194-1204.

[28] Zhang, L.L., Leng, S.Q., Zhu, R.Y., and Chen, J.M., 2011, Degradation of chlorobenzene by strain Ralstonia pickettii L2 isolated from a biotrickling filter treating a chlorobenzene-contaminated gas stream, Appl. Microbiol. Biotechnol., 91 (2), 407415.

[29] Ryan, M.P., Pembroke, J.T., and Adley, C.C., 2007, Ralstonia pickettii in environmental biotechnology: Potential and applications, J. Appl. Microbiol., 103 (4), 754-764.

[30] Purnomo, A.S., Sariwati, A., and Kamei, I., 2020, Synergistic interaction of a consortium of the brown-rot fungus Fomitopsis pinicola and the bacterium Ralstonia pickettii for DDT biodegradation, Heliyon., 6 (6), e04027.

[31] Wahyuni, S., Suhartono, M.T., Khaeruni, A., Purnomo, A.S., Asranudin, Holilah, and Riupassa, P.A., 2016, Purification and characterization of thermostable chitinase from Bacillus SW41 for chitin oligomer production, Asian J. Chem., 28 (12), 2731-2736.

[32] Khan, R., Patel, V., and Khan, Z., 2020, “Chapter 5 - Bioremediation of Dyes from Textile and Dye Manufacturing Industry Effluent" in Abatement of Environmental Pollutants Trends and Strategies, Eds. Singh, P., Kumar, A., and Borthakur, A., Elsevier, Netherlands, 107-125.

[33] Maniyam, M.N., Yaacob, N.S., Azman, H.H., Ab Ghaffar, N.A., and Abdullah, H., 2018, Immobilized cells of Rhodococcus strain UCC 0004 as source of green biocatalyst for decolourization and biodegradation of methyl orange, Biocatal. Agric. Biotechnol., 16, 569-578. 
[34] Zeng, G., Cheng, M., and Huang, D., 2015, Study of the degradation of methylene blue by semi-solidstate fermentation of agricultural residues with Phanerochaete chrysosporium and reutilization of fermented residues, Waste Manage., 38, 424-430.

[35] Michelle, Siregar, R.A.N., Sanjaya, A., Lucy, J., and Pinontoan, R., 2020, Methylene blue decolorizing bacteria isolated from water sewage in Yogyakarta, Indonesia, Biodiversitas, 21 (3), 1136-1141.

[36] Jayasinghe, C., Imtiaj, A., Lee, G.W., Im, K.H., Hur, H., Lee, M.W., Yang, H.S., and Lee, T.S., 2008, Degradation of three aromatic dyes by white rot fungi and the production of ligninolytic enzymes, Mycobiology, 36 (2), 114-120.

[37] Singh, S.N., 2015, Microbial Degradation of Synthetic Dyes in Wastewaters, Springer Nature, Switzerland.

[38] Liu, Y.N., Zhou, X., Wang, X., Liang, K., Yang, Z.K., Shen, C.C., Imran, M., Sahar, S., and Xu, A.W., 2017, Hydrogenation/oxidation induced efficient reversible color switching between methylene blue and leuco-methylene blue, RSC Adv., 7, 3008030085.

[39] Singh, R.L., Singh, P.K., and Singh, R.P., 2015, Enzymatic decolorization and degradation of azo dyes - A review, Int. Biodeterior. Biodegrad., 104, 2131.

[40] Purnomo, A.S., Rizqi, H.D., Harmelia, L., Anggraeni, S.D., Melati, R.E., Damayanti, Z.H., Shafwah, O.M., and Kusuma, F.C., 2019, Biodegradation of crude oil by Ralstonia pickettii under high salinity medium, MJFAS, 15 (3), 377-380.

[41] Purnomo, A.S., Maulianawati, D., and Kamei, I., 2019, Ralstonia pickettii enhance the DDT biodegradation by Pleurotus eryngii, J. Microbiol. Biotechnol., 29, 1424-1433.

[42] Deska, M., and Kończak, B., 2019, Immobilized fungal laccase as "green catalyst" for the decolourization process - State of the art, Process Biochem., 84, 112-123.

[43] Misal, S.A., and Gawai, K.R., 2018, Azoreductase: A key player of xenobiotic metabolism, Bioresour. Bioprocess., 5 (1), 17.
[44] Xu, L., Sun, J., Qaria, M.A., Gao, L., and Daochen, Z., 2021, Dye decoloring peroxidase structure, catalytic properties and applications: Current advancement and futurity, Catalysts, 11 (8), 955.

[45] Yang, C., Dong, W., Cui, G., Zhao, Y., Shi, X., Xia, X., Tang, B., and Wang, W., 2017, Highly efficient photocatalytic degradation of synergetic effect of $\mathrm{TiO}_{2}$ and P2ABSA, RS Adv., 7 (38), 23699-23708.

[46] Trandafilović, L.V., Jovanović, D.J., Zhang, X., Ptasińska, S., and Dramićanin, M.D., 2017, Enhanced photocatalytic degradation of methylene blue and methyl orange by $\mathrm{ZnO}: \mathrm{Eu}$ nanoparticles, Appl. Catal., B, 203, 740-752.

[47] Kurade, M.B., Waghmode, T.R., Kagalkar, A.N., and Govindwar, S.P., 2012, Decolorization of textile industry effluent containing disperse dye Scarlet RR by a newly developed bacterial-yeast consortium BL-GG, Chem. Eng. J., 184, 33-41.

[48] Bandounas, L., Pinkse, M., de Winde, J.H., and Ruijssenaars, H.J., 2013, Identification of a quinone dehydrogenase from a Bacillus sp. involved in the decolourization of the lignin-model dye, Azure B, New Biotechnol., 30 (2), 196-204.

[49] Dhanve, R.S., Kalyani, D.C., Phugare, S.S., and Jadhav, J.P., 2009, Coordinate action of exiguobacterial oxidoreductive enzymes in biodegradation of reactive yellow $84 \mathrm{~A}$ dye, Biodegradation., 20 (2), 245-255.

[50] Jadhav, S.B., Patil, N.S., Watharkar, A.D., Apine, O.A., and Jadhav, J.P., 2013, Batch and continuous biodegradation of Amaranth in plain distilled water by $P$. aeruginosa $\mathrm{BCH}$ and toxicological scrutiny using oxidative stress studies, Environ. Sci. Pollut. Res., 20 (5), 2854-2866.

[51] Ferreira, V.S., Magalhães, D.B., and Kling, S.H., 2000, $N$-demethylation of methylene blue by lignin peroxidase from Phanerochaete chrysosporium. Stoichiometric relation for $\mathrm{H}_{2} \mathrm{O}_{2}$ consumption, Appl. Biochem. Biotechnol., 84-86, 255-265.

[52] Griffin, B.W., and Ting, P.L., 1978, Mechanism of $\mathrm{N}$-demethylation of aminopyrine by hydrogen peroxide catalyzed by horseradish peroxidase, 
metmyoglobin, and protohemin, Biochemistry, 17 (11), 2206-2211.

[53] Kalme, S.D., Parshetti, G.K., Jadhav, S.U., and Govindwar, S.P., 2007, Biodegradation of benzidine based dye Direct Blue-6 by Pseudomonas desmolyticum NCIM 2112, Bioresour. Technol., 98 (7), 1405-1410.

[54] Kalyani, D.C., Patil, P.S., Jadhav, J.P., and Govindwar, S.P., 2008, Biodegradation of reactive textile dye Red BLI by an isolated bacterium Pseudomonas sp. SUK1, Bioresour. Technol., 99 (11), 4635-4641.

[55] Dawkar, V.V., Jadhav, U.U., Jadhav, S.U., and Govindwar, S.P., 2008, Biodegradation of disperse textile dye Brown 3REL by newly isolated Bacillus sp. VUS, J. Appl. Microbiol., 105 (1), 14-24.

[56] Bumpus, A., and Brock, B.J., 1988, Biodegradation of crystal violet by the white rot fungus Phanerochaete chrysosporium, Appl. Environ. Microbiol., 54 (5), 1143-1150.

[57] Chen, C.H., Chang, C.F., Ho, C.H., Tsai, T.L., and Liu, S.M., 2008, Biodegradation of crystal violet by a Shewanella sp. NTOU1, Chemosphere, 72 (11), 1712-1720.

[58] Wang, Q., Tian, S., and Ning, P., 2013, Degradation mechanism of methylene blue in a heterogeneous Fenton-like reaction catalyzed by ferrocene, Ind. Eng. Chem. Res., 53 (2), 643-649. 